\title{
Technological Capabilities of Medium-Sized Contractors in Indonesia
}

\author{
"Biemo W. Soemardi', Bayu Kusuma², Krishna S. Pribadi' and Sonny Yuliar ${ }^{3}$
}

First submission: 15 October 2019; Accepted: 7 September 2020; Published: 8 December 2021

To cite this article: Biemo W. Soemardi, Bayu Kusuma, Krishna S. Pribadi and Sonny Yuliar (2021). Technological capabilities of medium-sized contractors in Indonesia. Journal of Construction in Developing Countries, 26(2): 1-15. https://doi.org/10 $.21315 / j \mathrm{jcdc} 2021.26 .2 .1$.

To link to this article: https://doi.org/10.21315/jcdc2021.26.2.1

\begin{abstract}
The construction industry plays a significant role in national development and economic growth of Indonesia. Contractors are key actors in the construction industry and manage large amounts of construction resources and activities. While the demand for improving the nation's infrastructure is on the rise, the question remains whether the industry, especially contractors, will be able to fulfil this demand. This study investigates whether contractors include technological capabilities as an important part of their company strategies for addressing the dynamics of the construction industry. In particular, it aims to understand how contractors develop and improve their technological capabilities through a technological learning process (exploration, acquisition and internalisation). The investigation focuses on medium-sized contractors, who often play an important role as part of the supply chain for larger contractors. A model is developed to represent the dynamic interactions between key factors that influence the way contractors select and use technology to enhance their performance. Data were collected through a survey and were then used to map the contractors' development of technological capabilities. The study reveals that medium-sized contractors have yet to consider the development of technological capabilities as strategic. The results are expected to benefit the regulator and construction companies in Indonesia in their efforts to improve the performance of the country's construction industry.
\end{abstract}

Keywords: Contractor, Technological capability, Medium-sized, Indonesia, Construction

\section{INTRODUCTION}

The construction industry is an economic driver, which plays an important role in the prosperity of a country. The construction industry provides the infrastructure for other economic sectors, such as agriculture, energy, tourism, manufacturing, and trade (Budiwibowo et al., 2009). With the demand for infrastructure development increasing, the construction industry has grown. It currently contributes $10.4 \%$ of the national gross domestic product (GDP) and has promised jobs for more than 180,000 engineering and construction companies. Despite such promises, the industry is also facing challenges in term of competitiveness, a lack of skilled labour and low productivity. Although it has experienced a relatively steady increase in productivity in the last two decades, the Indonesian construction industry lags behind its counterparts in the Southeast Asian region. To address these challenges, contractors must implement improvements, including through

\footnotetext{
'Faculty of Civil and Environment Engineering, Bandung Institute of Technology, INDONESIA ${ }^{2}$ Ministry of Public Works and Housing, INDONESIA

${ }^{3}$ School of Architecture, Planning and Policy Development, Bandung Institute of Technology, INDONESIA

"Corresponding author: b.soemardi@itb.ac.id
} 
their use of technology. Many new forms of technology can be used to improve productivity (Loosemore, 2014), cost-effectiveness, safety and sustainability (Sepasgozar, Loosemore and Davis, 2016). Each form of technology has specific characteristics and construction companies can adopt the technologies that are most appropriate for their work and business models.

The construction industry consists of many actors, including service providers (consultants and contractors), service users (public and private), regulators and communities, along with their respective supply chains (Osei, 2013). Due to the level of complexity of the work, the amount of funds and labour involved and the multiplier effects for both upstream and downstream industries, contractors occupy a strategic position in the construction industry (Julison, Wardani and Wibowo, 2017). They are considered the main actors for the advancement of the industry. To improve their competitiveness, contractors must be able to cope with dynamic changes in the business environment. These changes include business diversification, proactivity, innovation and increasing internal capabilities regarding leadership, contract management, and health and safety management. In addition, to alleviate productivity issues, the construction industry must consider changing their business practices. This includes rethinking the design and engineering process, improving procurement and supply chain management, enhancing on-site execution, reskilling the workforce and using digital and advanced technologies and new materials (McKinsey Global Institute, 2017). For many contractors, changing the ways in which they operate means a significant shift from traditional methods that mostly rely on labour capabilities to more technologically oriented ones. However, as Pamulu (2010) noted, contractors in Indonesia do not yet consider technological capability to be an important factor for securing contracts.

The steadily increasing size of the industry, coupled with the government's desire to accelerate the development of the nation's infrastructure, means that the Indonesian construction industry is currently facing at least two challenges: (1) It is facing increasing demand for improved delivery and quality of construction products and (2) Open market conditions have forced contractors to be better prepared and more competitive against foreign contractors to secure construction contracts in their own country. Such dynamic conditions have forced Indonesian contractors to find ways to enhance their capacity, which includes improving their technological capability.

At present, knowledge of Indonesian contractors' attitudes to technology, including their strategies for adopting and using technology as a resource for conducting business, is still extremely limited. This study aims to determine whether contractors implement various strategies to develop their technological capabilities. The conceptual framework developed in this study will enable decision-makers (practitioners and regulators) to formulate policies to promote wider and better use of technology in the construction industry.

\section{LITERATURE REVIEW}

Competitiveness and productivity are the two main issues currently faced by contractors in Indonesia. Both issues greatly influence the ability of contractors to win contracts for projects and complete them successfully. In the long run, competitiveness comes from the ability to consistently deliver construction products at a lower cost and faster than competitors. 


\section{Development of the Construction Industry in Indonesia}

Construction investment in Indonesia continues to be the largest in Asia and is significantly more than in other South East Asian countries. The rapid development of all industry sectors and increased domestic demand for public services has driven investment in construction. Over the last five years, the Indonesian government's focus on infrastructure development has boosted spending on construction, in the form of both government funding and public-private partnership schemes. For the next five years (2020-2025), infrastructure will remain the focus of development and the private sector is expected to account for a larger portion of investment in the area. The promise for these next five years is more construction for infrastructure development, which requires not only significant funding but also advanced technology and methods that result in increased productivity and efficiency in the industry. The structure of construction companies has remained Indonesia relatively unchanged; the industry is dominated by small and medium-sized companies. Specialisation is rare as most contractors must compete in a very tight market, especially in areas where the market is particularly concentrated (e.g., in large capital cities and Java Island). Medium-sized contractors account for around $18 \%$ of approximately 131,500 construction companies. Although the majority of the construction market $(80 \%)$ is absorbed by large construction companies, which represent approximately $1 \%$ of total construction companies, mediumsized contractors are considered important for the overall structure of the industry. In addition to carrying out private housing and residential building projects, medium-sized contractors often function as subcontractors for public infrastructure projects (Soemardi and Pribadi, 2019). At the national level, medium-sized contractors have positioned themselves as an important element in the structure of the construction industry. Although most of them are established and operating in the nation's capital, the existence of medium-sized contractors in every provincial capital plays an important role in ensuring the sustainability of regional development.

In terms of technology and knowledge in the construction industry, there is little to reveal since no formal or official efforts have been made by the government to monitor those resources. Construction technology and knowledge are managed by individual construction firms. However, a small number of construction firms have implemented technology or knowledge management in their companies. However, information on these measures is generally not publicly accessible. No policy on technology and knowledge management has been issued by the government. Further research is required on the technology used by the construction industry, as well as the technology created by Indonesian scholars and companies (Abduh and Pribadi, 2014). The use of construction technology in Indonesia has evolved along with the development of the construction industry, which is both directly and indirectly influenced by the country's political conditions in the country. Modern construction practices in Indonesia were first used during the Dutch colonial era, which saw the construction of many monumental historical buildings and public infrastructures. Such practices evolved throughout various stages of national development until today and are reflected in the country's many modern structures, including tall modern buildings, high-speed trains, ports and airports. 


\section{Technology in the Construction Industry}

As in other industries, technology is used in the construction industry to transform material inputs into desired outputs (Egmond and Smook, 2001). Technology is a complex concept and, as Sazali, Raduan and Suzana (2012) observed, has various meanings in a variety of contexts. In principle, technology consists of four closely related components: (1) Knowledge, (2) Engineering, (3) Products and (4) Organisations. In this study, technology is defined as a product (object, activity and knowledge) that is produced through the transformation of materials based on their properties and features to perform a desired function. Contractors must have a mastery of the appropriate technology to be able to transform resources in the completion of construction projects. The products of construction (buildings, roads, bridges, etc) are also technology, and the process of construction involves technologies in the form of equipment, materials and working methods.

Although the acquisition of technology can be outsourced, the ability to effectively use hardware cannot be obtained easily. It must be developed locally through various measures, including a purposive allocation of technological knowledge, along with other resources, to the assimilation and adaptation of existing technologies and/or the creation of new technologies (Dahlman and Westphal, 1981). A systematic effort of technological learning is required to improve technological capability in the construction industry (Marcelle, 2004). In this study, technological learning refers to the ability of the contractors to select, absorb, adapt and develop technology (hardware and facilities, codified knowledge and information, tacit human knowledge and skills, and organisational culture, routine and processes), which are manifested in skills, knowledge, experience and organisational systems, so that the technical functions of contractors as executors of construction can be fulfilled.

As Amaratunga, Rameezdeen and Shanmugam (2005) emphasised, the real power of technology is not in its ownership but in technological capabilities, which consist of operative, transactional, innovative and supportive abilities. Technological capability is crucial for companies wishing to increase their competitiveness and improve their performance (Chinowsky, 2001). Definitions of technological capability are diverse (Alina et al., 2012; Nurazwa, Siti Norezam and Halim, 2014). In this study, technological capability is defined as the ability of an organisation to effectively and efficiently use its technological resources to create competitive advantages.

Technological capability significantly affects the performance of a company (Egmond and Smook, 2001). However, it should be noted that the absorption and adoption of technology cannot be achieved by simply acquiring and employing the technology but also requires effort to develop the capability to master the technology; the latter is a process of gathering or accumulating technological capabilities and should be considered a key investment. Technological learning strategies play a decisive role in effectively guiding and monitoring firm-level technological capability (Sobanke et al., 2014). For contractors, developing a learning mechanism system is generally seen as a technical process (Sekarsari, 2005). Liu, Qian and Chen (2006) outlined the relationship between learning technology, technological capabilities, and company performance, and Marcelle (2004) concluded that improving the effectiveness of capacity building and technological learning requires the simultaneous, proportionate and systemic management of five key elements: (1) Financing, (2) Management and coordination, (3) Culture 
and leadership, (4) Managing relationships with suppliers and (5) Innovation systems. To achieve an appropriate level of technological capability, a company can use internal and external learning mechanisms. Examples of the latter include collaborations with government research laboratories and networking with other companies (Kumar, Kumar and Persaud, 1999).

An improved understanding of construction technology can help companies to identify opportunities for improvement and seek competitive advantages. The process of introducing new technology to the construction industry is slow compared to other industries, especially in the field of process automation using industrial robotics (Skibniewski and Chao, 1992). Companies can improve their technological knowledge and strengthen their technological capabilities by seeking out and using external technology (Tsai and Wang, 2008). Oti-Sarpong and Leiringer (2016) asserted that when carrying out construction projects, contractors use a combination of tacit and explicit technology, including plant construction and equipment, project engineering, construction and management processes, intuitive ideas included in project design and the management of construction processes. This shows that contractors can learn about technology by implementing construction projects. Five approaches to learning technology can be identified: (1) Individual networking, (2) Organisation, (3) Experimentation, (4) Reading and (5) Attending courses and seminars (Wasif, Josephson and Styhre, 2008). Contractors must facilitate individual learning needs, which ultimately accumulate to become corporate learning. To facilitate the learning process, contractors can use several mechanisms, both at the locus of learning in the project and within the organisation. These mechanisms include pre-learning of system processes, experience accumulation, knowledge articulation, codification/storage and dissemination/distribution (Mahdiputra et al., 2005).

Various authors have described the need for a well-organised system to improve a company's technological capabilities (Marcelle, 2004; Liu, Qian and Chen, 2006; Panda and Ramanathan, 1996). Improving technological capabilities involves two equally important processes: internal processes, which are directly controlled by the company, and external processes or boundaries, which are only partially controlled by the company. Improving technological capabilities is considered a strategic investment and is closely related to other company strategies. It requires time, patience and monitoring (Amaratunga, Rameezdeen and Shanmugam, 2005).

\section{Model of Contractor Technological Capability Building}

A solid understanding of technology can help contractors effectively use appropriate technology to increase their competitiveness in dealing with business dynamics. For contractors, the technological capability building process reflects the dynamic relationships within the construction business environment and the contractor's corporate strategy, technological capabilities and performance. The business environment is an external condition to which a contractor must respond appropriately to gain competitive advantage. It refers to market demands, competition, business and economic conditions, regulatory conditions and the environmental and social provisions that govern the industry.

Technological capability development should be part of the contractor's formal strategy directed at the achievement of the contractor's goal through the realisation of a set of targeted performances. In other words, technological 
capability development describes what technologies are adopted and how they are mastered and applied to support the achievement of the contractor's goals. The development of technological capability should be part of the company's policy and should include guidelines on how technology will be obtained and how it should be mastered and employed and, to some extent, improved and developed. Using this understanding, a conceptual framework of contractor technological capability building was developed for this study and is presented in Figure 1.

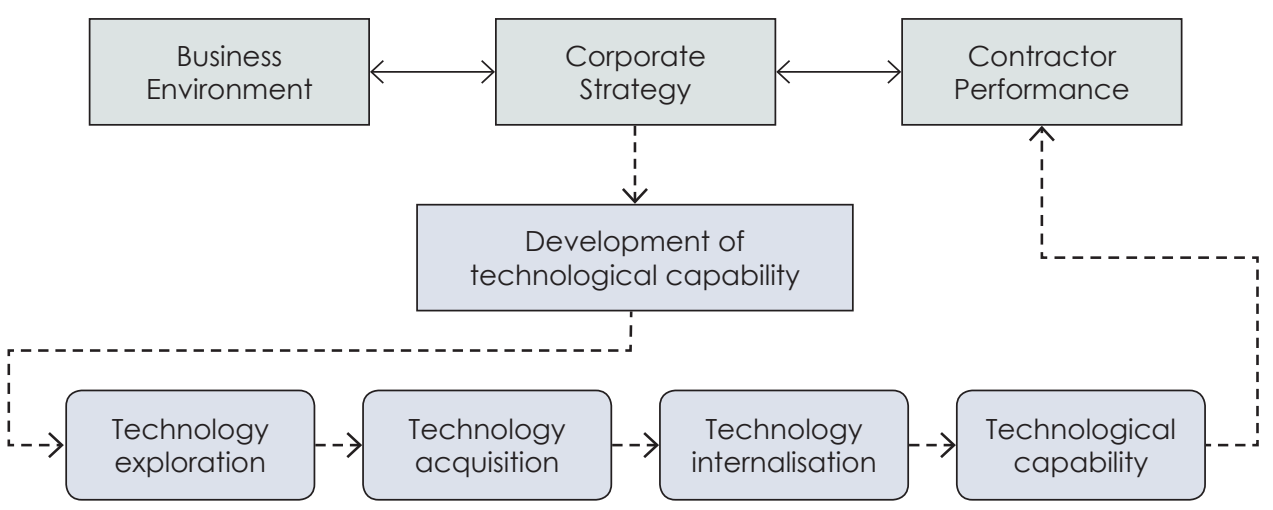

Figure 1. Conceptual framework for contractor technological capability building

The framework consists of three main sequential components: (1) Business environment, (2) Corporate strategy and (3) Corporate performance. Contractors must develop a strategy, based on an analysis of their business environment, to achieve efficient company performance. One important element of achieving the desired level of performance is technological capability, which must be continuously enhanced. Technological capability is obtained through technological learning, which consists of three sequential phases. The first phase involves the introduction of technology into the organisation. Prior to the adoption of any technology, contractors shall explore various technologies that are currently available, either through direct solicitation or by means of external professional assistance. Acquisition of technology is achieved through the process of matching the companies' internal (strength and weakness) characteristics with their business objectives. Once the technology has been adopted, the next phase is to master and exploit it for the contractor's business purposes. Internalisation of technology is the key to the successful adoption of technology, which must be permeate across all organisation's structure. The last phase is the exploitation of technology which shall also be accompanied by the development of technological capability. Up to this phase, the contractor must decide the extent to which they will make use of the current technology, which may eventually become obsolete or ineffective. Using that concept as a basis, this study aims to understand the different ways in which contractors are developing technological capability as part of their corporate strategy to achieve certain performance levels. 


\section{RESEARCH METHOD}

This work is part of a larger study that examines how contractors in Indonesia use and develop technology as part of their business strategy. This work aims to determine whether contractors develop different technological capacity development strategies based on their backgrounds and business settings. This aim is achieved by soliciting opinions and experiences from construction practitioners on how technology is used and developed by contractors.

Data for this study were collected through a set of questionnaires distributed to practitioners and managers representing construction firms with at least 15 years' practical construction experience. The questionnaires were developed based on the aforementioned conceptual framework, which is aimed at obtaining information on variables representing the dynamics of the technological capability development process. Respondents were asked to rate, on a psychometric Likert scale, their perceptions regarding general information on their company, the business environment, the company's corporate strategy, company performance, technological capability development, technological exploration, technological acquisition, technological internalisation and technological capability. Following the structural model analysis, a limited interview was also conducted to obtain further insights into the responses.

The "Business environment" variable reflects how contractors respond to the dynamics of the industry when determining their business objectives. The "Corporate strategy" variable is used to discover whether contractors formally devise particular strategic steps in response to the dynamics of the industry. The "Development of technological capability" variable reflects initiatives undertaken by contractors with respect to the use and development of technology. This variable is expanded to represent more detailed processes of capability building. The "Exploration of technology" variable determines how contractors obtain information on technology, while the "Technological acquisition" variable is used to understand the different ways in which contractors adopt and master technology. The "Internalisation of technology" variable is used to understand the mechanism by which contractors deploy the technology prior to its implementation, and the "Technological capability" variable is used to predict the results of technological learning and to measure the success of a contractor in employing the technology. The final variable, "Contractor performance", is used to measure the success of a contractor's business activities.

\section{DATA ANALYSIS}

Questionnaires were distributed to individual practitioners at the managerial level, including operational and technical directors and engineering/project managers, with more than 15 years' experience in construction and various infrastructure projects. Forty-six responses were received from individuals representing large contractors and 54 from those representing medium-sized contractors. Small contractors were intentionally excluded from the study since they mostly rely on labour-intensive, traditional construction methods. The respondents were either directors of operations or engineering managers representing 32 contractors from the province capital of Bandung, 11 contractors from the national capital of Jakarta and the surrounding area, six contractors from the western region and 
five contractors from the eastern region of Indonesia. On average, the contractors had been in operation for more than five years, and most had less than 50 permanent employees. The medium-sized contractors handled an average of two to three projects yearly and each employed 10 to 15 project team members.

\section{Mapping of Contractor Technological Capability Development}

A structural model was constructed to examine the dynamic relationships between variables. The model consists of eight variables, constructed from 25 latent variables and 123 indicators, as depicted in Table 1.

Table 1. Variables in the technological capability model

\begin{tabular}{|c|c|c|c|c|}
\hline \multicolumn{2}{|c|}{ Variables } & \multicolumn{2}{|r|}{ Latent Variables } & \multirow{2}{*}{$\frac{\text { Indicators }}{6}$} \\
\hline $\mathrm{BE}$ & Business & BE. 1 & Business challenges/obstacles & \\
\hline & environment & BE. 2 & Business issues & 6 \\
\hline \multirow[t]{2}{*}{ CS } & Corporate & CS.1 & Anticipative action & 10 \\
\hline & & CS.2 & Project implementation & 4 \\
\hline \multirow[t]{2}{*}{ DT } & Development of & DT.1 & Influencing factors & 5 \\
\hline & $\begin{array}{l}\text { technological } \\
\text { capability }\end{array}$ & DT.2 & Learning consideration & 12 \\
\hline \multirow[t]{4}{*}{ ET } & Exploration of & ET.1 & Technology categorisation & 4 \\
\hline & technology & ET.2 & Technology aggressiveness & 5 \\
\hline & & ET.3 & Prioritisation of technology & 4 \\
\hline & & ET.4 & Business intelligent data & 4 \\
\hline \multirow[t]{5}{*}{ AT } & Acquisition of & AT.1 & Equipment availability & 5 \\
\hline & technology & AT.2 & $\begin{array}{l}\text { Research and development (R\&D) } \\
\text { approach }\end{array}$ & 4 \\
\hline & & AT.3 & Budget for technology & 1 \\
\hline & & AT.4 & Technology testing & 1 \\
\hline & & AT.5 & Learning mechanism & 1 \\
\hline \multirow[t]{3}{*}{ IT } & Internalisation & IT.1 & Corporate information flow & 4 \\
\hline & of technology & IT.2 & Data system and documentation & 5 \\
\hline & & IT.3 & Training approach & 4 \\
\hline \multirow[t]{5}{*}{ TC } & Technological & TC. 1 & Implementation of IT & 10 \\
\hline & capability & TC.2 2 & $\begin{array}{l}\text { Implementation of advanced } \\
\text { technology }\end{array}$ & 12 \\
\hline & & TC.3 & Implementation of new technology & 1 \\
\hline & & TC. 4 & Evaluation of technological capability & 1 \\
\hline & & TC. 5 & Impact of technological capability & 4 \\
\hline \multirow[t]{2}{*}{$\mathrm{CP}$} & Contractor's & CP.1 & Market share & 4 \\
\hline & performance & CP.2 & Quality/project performance & 6 \\
\hline
\end{tabular}


To determine the dynamic relationships between the variables, a structural equation modelling (SEM) technique was used. This technique has been successfully used to address various dynamic modelling issues in construction (Chinda and Mohamed, 2008; Chen et al., 2012; Molwus, Erdogan and Ogunlana, 2017). The SEM model was used to study the dynamic relationships between exogenous variable (Technological capability building) and various latent variables that affect the successful implementation of technology in construction companies. The model, as shown in Figure 2 helps study the relationship to explicitly model the direct and indirect correlative effects amongst latent variables. The "Business environment" variable is assumed to influence how the company establishes its business strategy, which, in turn, guides the achievement of the "Contractor's performance". The path of developing the company's technological capability refers to the construction company's strategy, which represents a sequential process consisting of the "Development of technological capability", the "Exploration of technology", the "Acquisition of technology" and "Internalisation of technology". This is then reflected in the company's "Technological capability" and performance.

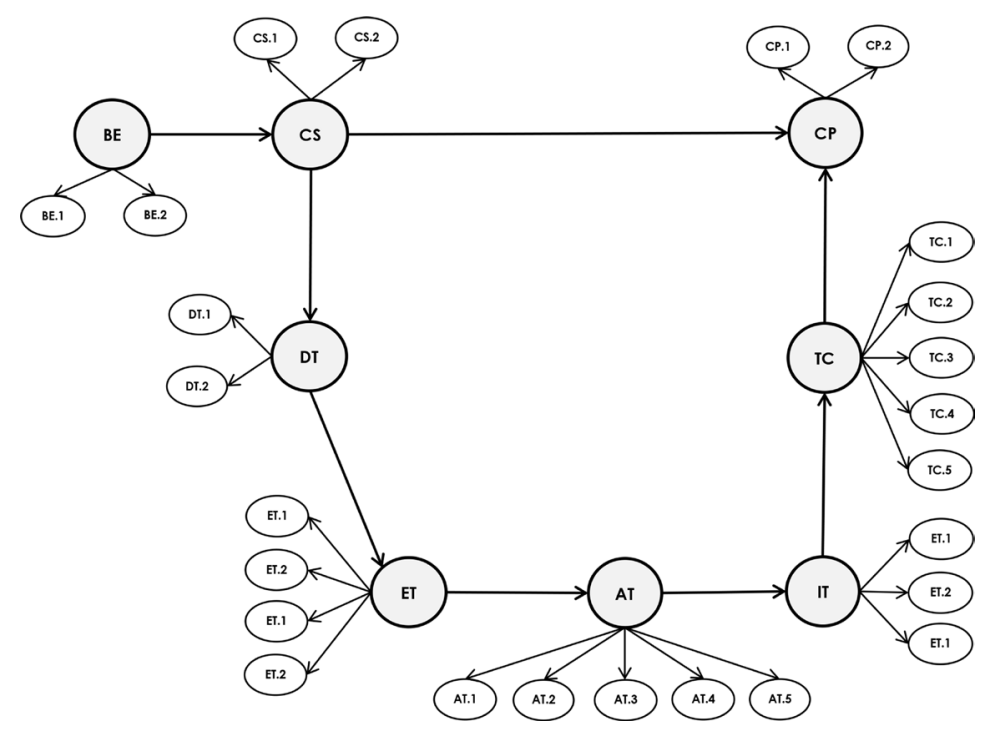

Figure 2. Structural model of contractor technological capability building

The validity and reliability of the model are presented in Table 2 . Since the composite reliability of almost all variables is more than $90 \%$, and all variables have acceptable convergence validity (average variance extracted, AVE > 0.5), the model is acceptable (Sarstedt, Hair and Ringle, 2016). However, the discriminant validity is low, and no variable shows significant relationships. In this respect, three of the variables-"Corporate strategy", "Development of technological capability" and "Acquisition of technology"-are categorised as "Very weak" $\left(R^{2}<0.25\right)$. The other variables-"Exploration of technology", "Internalisation of technology", "Technological capability" and "Contractor's performance"-are categorised as "Weak" ( $\left.R^{2}<0.5\right)$. 
Table 2. Value of the estimation model for medium-sized contractor

\begin{tabular}{|c|c|c|c|c|c|}
\hline \multicolumn{2}{|c|}{ Variable } & \multirow{2}{*}{$\begin{array}{c}\begin{array}{c}\text { Composite } \\
\text { Reliability }\end{array} \\
0.814\end{array}$} & \multirow{2}{*}{$\begin{array}{l}\text { AVE } \\
0.523\end{array}$} & \multirow[t]{2}{*}{$R^{2}$} & \multirow[t]{2}{*}{ Relation } \\
\hline 1 & Business environment & & & & \\
\hline 2 & Corporate strategy & 0.941 & 0.640 & 0.040 & Very weak \\
\hline 3 & $\begin{array}{l}\text { Development of technological } \\
\text { capability }\end{array}$ & 0.957 & 0.650 & 0.036 & Very weak \\
\hline 4 & Exploration of technology & 0.901 & 0.508 & 0.436 & Weak \\
\hline 5 & Acquisition of technology & 0.875 & 0.584 & 0.228 & Very weak \\
\hline 6 & Internalisation of technology & 0.908 & 0.531 & 0.387 & Weak \\
\hline 7 & Technological capability & 0.936 & 0.619 & 0.290 & Weak \\
\hline 8 & Contractor's performance & 0.918 & 0.618 & 0.251 & Weak \\
\hline
\end{tabular}

All the path coefficients in the SEM framework are non-zero with a $90 \%$ confidence level. This indicates that significant relationships exist between the observed variables and the latent variables. The results of a partial least square analysis (PLS-SEM) indicate the paths taken by medium-sized contractors in developing their technological capability at $10 \%$ significance level. As Table 3 shows, almost all constructs have weak or even very weak effects. This suggests a lack of significant relationships between the variables.

Table 3. Dimension and construct path coefficients

\begin{tabular}{lccccc}
\hline Path & $\begin{array}{c}\text { Path } \\
\text { Coefficient }\end{array}$ & t-Statistic & p-Values & $\mathbf{f}^{2}$ & Impact \\
\hline $\begin{array}{l}\text { Business environment } \rightarrow \\
\text { Corporate strategy }\end{array}$ & 0.199 & 1.078 & 0.281 & 0.041 & No \\
$\begin{array}{l}\text { Corporate strategy } \rightarrow \\
\text { Development of } \\
\text { technological capability }\end{array}$ & -0.190 & 1.310 & 0.190 & 0.038 & No \\
$\begin{array}{l}\text { Development of } \\
\text { technological capability } \rightarrow\end{array}$ & 0.661 & 8.029 & 0.000 & 0.774 & Substantial \\
$\begin{array}{l}\text { Exploration of technology } \\
\begin{array}{l}\text { Exploration of technology } \\
\rightarrow \text { Acquisition of technology }\end{array}\end{array}$ & 0.478 & 3.698 & 0.000 & 0.295 & Weak \\
$\begin{array}{l}\text { Acquisition of technology } \\
\rightarrow \text { Internalisation of }\end{array}$ & 0.622 & 6.327 & 0.000 & 0.631 & Moderate \\
$\begin{array}{l}\text { technology } \\
\text { Internalisation of technology } \\
\rightarrow \text { Technological capability }\end{array}$ & 0.538 & 5.324 & 0.000 & 0.407 & Weak \\
$\begin{array}{l}\text { Technological capability } \rightarrow \\
\text { Contractor's performance } \\
\begin{array}{l}\text { Corporate strategy } \\
\rightarrow \text { Contractor's performance }\end{array}\end{array}$ & 0.357 & 3.609 & 0.000 & 0.161 & No \\
\hline
\end{tabular}


The effects of the exogenous latent variables on the endogenous latent variables are expressed in path parameter coefficients, as shown in Figure 3, which can be explained as follows. The business environment only slightly influences corporate strategy. Likewise, corporate strategy has only a very weak influence on the development of technological capability in opposite ways. Technological capability development substantially impacts the exploration of technology. However, the relationship between the exploration of technology and the acquisition of technology is weak. Similarly, the internalisation of technology has a weak impact on technological capacity. However, the acquisition of technology has a moderate influence on the internalisation of technology. Perhaps the most important finding is the absence of a relationship between technological capability and a contractor's performance. Likewise, the model also suggests that a contractor's corporate strategy has little influence on its performance.

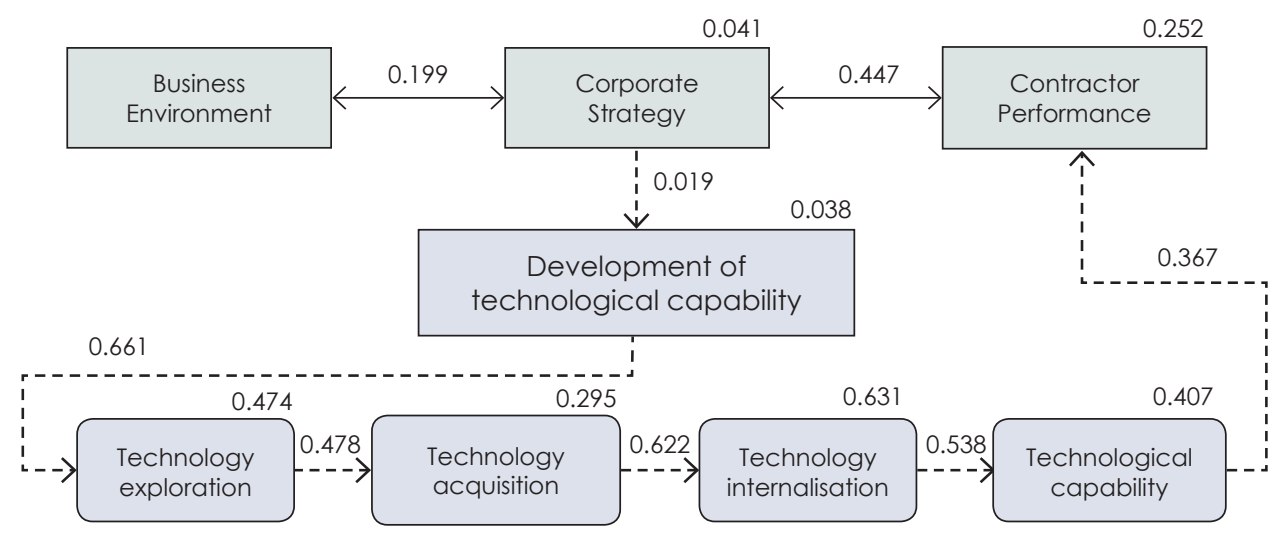

Figure 3. Technological capability building map for medium-sized contractors

Contrary to the assumption in the proposed conceptual model, the results of the analysis show that middle-sized contractors have yet to fully comprehend the importance of technology for doing business. In general, the model suggests that contractors do not consider the business environment as important for formulating their corporate's strategy. It is also apparent that although technology is considered important, contractors have yet to include technological capability building in their corporate strategy. Furthermore, in-depth interviews with several respondents revealed several important insights that corroborate these findings.

For medium-sized contractors, the need for and use of technology are driven more by the technical requirements and demands of employers than by the initiative of the contractors themselves. Currently, they still consider investment in technology too expensive, and yet to warrant getting a job. However, despite the lack of consideration to including technological capability in their corporate strategies, medium-sized contractors seem to have a strong interest in technology and acknowledge that exploring technology is a key step towards developing technological capability. Overall, the attitude of contractors operating in the capital city of Jakarta and the provincial capital of Bandung are more inclined to adopt new technology than those from other areas of Indonesia. The majority of contractors from localities in the western and eastern parts of Indonesia are general contractors working mostly on common building projects and residential or 
simple government infrastructure projects, while many of those operating in major cities, such as Jakarta and Bandung, also work as specialist subcontractors for large building and infrastructure projects. These conditions may explain why they are more amenable to adopting new technology.

In conclusion, the model suggests that medium-sized contractors are relatively good at understanding the importance of exploring the technological requirements for developing their technological capability. However, they are still uncertain of how to acquire technology due to limited resources. Though they perform slightly better in internalising technology, they are also hampered in this respect by a lack of capable human resources and training and other management issues. Medium-sized contractors do not appear to be particularly successful in converting technology into technological capability. As a result, medium-sized contractors often fail to capitalise on technology. Therefore, it is understandable that they believe successful company performance is unrelated to technological capabilities and is more influenced by other factors and that they, therefore, do not incorporate technological capabilities into their corporate strategies.

\section{CONCLUSION}

This article presents some reflections on the development of contractors' technological capabilities. It proposes a conceptual framework for mapping the process by which contractors develop technological capability. The results of the analysis of the relationship between variables show that this framework can be used to map the pattern of technological capability development carried out by contractors in Indonesia.

Currently in Indonesia, knowledge of construction technology and how construction companies respond to it, particularly how they develop technological capabilities, is limited. The model developed in this study demonstrates how the process of developing technological capabilities represents a step in responding to the dynamics of the business environment and a way of achieving a company's performance goals. By synthesizing theoretical perspectives, this model also provides opportunities to improve our understanding of the process of developing technological capabilities.

Despite the limited sample size, this study has succeeded in gathering relevant information in terms of the consistency, clarity and completeness of the answers provided by respondents. The subjective assessments of respondents have provided insights into how medium-sized contractors value technology and the need to develop technological capabilities. The multivariate analysis is successful in identifying factors that contractors should consider to develop their technological capabilities in an integrated and comprehensive way. The descriptive analysis has provided an interesting account of the pattern of technological capability development among medium-sized contractors. This study also offers an overview of how contractors understand their technological capabilities in relation to the dynamics of the construction industry and their efforts to achieve performance goals. It also reveals that the environmental setting plays an important role. A detailed analysis of the above pattern indicates that contractors in large major cities adopt different approaches than their counterparts in other areas.

This study concludes that medium-sized contractors consider it necessary to formulate a company strategy to guide the achievement of the company's 
performance goals. However, when developing such a strategy, they do not necessarily consider the dynamics of the existing business environment. Medium contractors also believe that, at a certain level, technological capabilities will help them to improve their performance and that, therefore, they need to develop their technological capabilities. Unlike their medium-sized counterparts, many large Indonesian contractors have developed their technological capability through their internal R\&D and training departments (Soemardi, Kusuma and Abduh, 2020). To encourage medium-sized companies to include technology in their strategies, the government and the industry must work together to create an environment that will enable these contractors to invest in technology. Such endeavours may include tax incentives, joint technological capability development between large and medium-sized contractors and incentives for joint training and development of technology with academia.

The study also shows that further research is needed to further explore the relationship between the business environment and company strategy and how contractors can include technological capability development policies in their strategies. This will provide valuable insights into how the performance of contractors can be improved through improved technological capabilities. This may contribute to the efforts of the government to involve construction contractors in national development.

\section{REFERENCES}

Abduh, M. and Pribadi, K.S. (2014). Harmonizing the Indonesian construction resources supply chain. Paper presented at the Asia Construct Conference 2014. Hong Kong, 13-14 November.

Alina, S., Eła W., Nor Hazana A. and Nor Kamariah, K. (2012). In Proceedings International Conference of Technology Management, Business and Entrepreneurship 2012 (ICTMBE20 12). Melaka, Malaysia: ICTMBE2021, 279-299.

Amaratunga, R.D.G., Rameezdeen, R. and Shanmugam, M. (2005). Transfer of technology in construction: Absorption capacity and internalisation. In L. Ruddock, D. Amaratunga, G. Aouad, R. Haigh, M. Kagioglou and M. Sexton (eds.), Proceedings of the Fifth International Postgraduate Research Conference, 14-15 April 2005, University of Salford. Vol. 2. Salford, UK: Research Institute for the Built and Human Environment, 628-636.

Budiwibowo, A., Trigunarsyah, B., Abidin, I.S. and Soeparto, H.G. (2009). Competitiveness of the Indonesian construction industry. Journal of Construction in Developing Countries, 14(1): 51-68.

Chen, W.T., Chen, T.T, LU, C.S. and Liu S.S. (2012). Analyzing relationships among success variables of construction partnering using structural equation modelling: A case study of Taiwan's construction industry. Journal of Civil Engineering and Management, 18(6): 783-794. https://doi.org/10.3846/1392 3730.2012.735062.

Chinda, T. and Mohamed, S. (2008). Structural equation model of construction safety culture. Engineering, Construction and Architectural Management, 36(1): 114-131. https://doi.org/10.1108/09699980810852655.

Chinowsky, P. (2001). Strategic management in engineering organizations. Journal of Management in Engineering, 17(2): 60-68. https://doi.org/10.1061/ (ASCE)0742-597X(2001)17:2(60). 
Dahlman, C.J. and Westphal, L.E. (1981). The meaning of technological mastery in relation to transfer of technology. Annals of the American Academy of Political and Social Sciences, 458(1): 12-26.

Egmond, E.V. and Smook, R.A. (2001). The technology mapping methodology for benchmarking the construction performance. In Proceedings: CIB World Building Congress. Salford, UK: CIB, 1-12.

Julison, B., Wardani, S.P.R. and Wibowo, M.A. (2017). Innovation performance of large contractor in Indonesia: Influencing factors and its impact on firm's performance. Procedia Engineering, 171: 370-378. https://doi.org/10.1016/ j.proeng.2017.01.346.

Kumar, V., Kumar, U. and Persaud, A. (1999). Building technological capability through importing technology: The case of Indonesian manufacturing industry. The Journal of Technology Transfer, 24: 81-96. https://doi.org/ 10.1023/A:1007728921126.

Liu, J.-J., Qian, J.-Y. and Chen, J. (2006). Technological learning and firm-level technological capability building: Analytical framework and evidence from Chinese manufacturing firms. International Journal of Technology Management, 36(1/2/3): 190-208. https://doi.org/10.1504/IJTM.2006.009968.

Loosemore, M. (2014). Improving construction productivity: A subcontractor's perspective. Engineering, Construction and Architectural Management, 21 (3): 245-260. https://doi.org/10.1108/ECAM-05-2013-0043.

Mahdiputra, S., Giddings, B., Hogg, K. and Daws, M. (2005). Organisational learning in construction companies. In L. Ruddock, D. Amaratunga, G. Aouad, R. Haigh, M. Kagioglou and M. Sexton (eds.), Proceedings of the Fifth International Postgraduate Research Conference, 14-15 April 2005, University of Salford. Vol. 2. Salford, UK: Research Institute for the Built and Human Environment, 696-711.

Marcelle, G.M. (2004). Technological Learning: A Strategic Imperative for Firms in the Developing World. Cheltenham/Northampton: Edward Elgar Publishing.

McKinsey Global Institute (2017). Reinventing Construction: A Route to Higher Productivity. New York: McKinsey \& Company.

Molwus, J.J., Erdogan, B. and Ogunlana, S. (2017). Using structural equation modeling (SEM) to understand the relationship among critical success factors (CSFs) for stakeholder management in construction. Engineering Construction and Architectural Management, 24(3): 426-450. https://doi.org/10.1108/ECAM -10-2015-0161.

Nurazwa, A., Siti Norezam, O. and Halim, M.L. (2014). A review of technological capability and performance relationship in manufacturing companies. In Proceedings: 2014 International Symposium on Technology Management and Emerging Technologies. Danvers, MA: Institute of Electrical and Electronics Engineers (IEEE), 193-198. https://doi.org/10.1109/ISTMET.2014.6936505.

Osei, V. (2013). The construction industry and its linkages to the Ghanaian economy: Policies to improve the sector's performance. International Journal of Development and Economic Sustainability, 1 (1): 56-72.

Oti-Sarpong, K. and Leiringer, R. (2016). The role of learning in construction technology transfer: A "SCOT" perspective. In P.W. Chan and C.J. Neilson (eds.), Proceedings of the 32nd Annual Conference. Vol. 2. Manchester: Association of Researchers in Construction Management (ARCOM), 699-708. 
Pamulu, M.S. (2010). Strategic management practices in the construction industry: A study of Indonesian enterprises. PhD diss. Queensland University of Technology.

Panda, H. and Ramanathan, K. (1996). Technological capability assessment of a firm in the electricity sector. Technovation, 16(10): 561-588. https://doi.org/ 10.1016/S0166-4972(97)82896-9.

Sarstedt, M., Hair, J.F. and Ringle, C.M. (2016). Estimation issues with PLS and CBSEM: Where the bias lies. Journal of Business Research, 69: 3998-4010. https://doi.org/10.1016/j.jbusres.2016.06.007.

Sazali, A.W., Raduan, C.R. and Suzana, I.W.O. (2012). Defining the concepts of technology and technology transfer: A literature analysis. International Business Research, 5(1): 61-71. https://doi.org/10.5539/ibr.v5n1p61.

Sekarsari, J. (2005). Knowledge management employed by firms: A study of the Indonesian construction contractors. Paper presented at the Seminar 25 Tahun MRK ITB, Bandung, Indonesia, 18-19 August.

Sepasgozar, S., Loosemore, M. and Davis, S. (2016). Conceptualising information and equipment technology adoption in construction: A critical review of existing research. Engineering, Construction and Architectural Management, 23(2): 158-176. https://doi.org/10.1108/ECAM-05-2015-0083.

Skibniewski, M.J. and Chao, L.C. (1992). Evaluation of advanced construction technology with AHP method. Journal of Construction Engineering and Management, 118(3): 577-593. http://dx.doi.org/10.1061/(ASCE)0733-9364 (1992) 118:3(577).

Sobanke, V., Adegbite, S., llori, M. and Egbetokun, A. (2014). Determinants of technological capability of firms in a developing country. Procedia Engineering, 69: 991-1000. https://doi.org/10.1016/j.proeng.2014.03.081.

Soemardi, B. and Pribadi, K.S. (2019). Country Report: Indonesia Construction Sector. Madurai, India: AsiaConstruct.

Soemardi, B., Kusuma, B. and Abduh, M. (2020). Technology assessment in Indonesian construction industry. IOP Conference Series: Material Sciences and Engineering, 849: 012077. https://doi.org/10.1088/1757-899X/849/1/012077.

Tsai, K.H. and Wang, J.C. (2008). External technology acquisition and firm performance: A longitudinal study. Journal of Business Venturing, 23: 91-112. https://doi.org/10.1016/j.jbusvent.2005.07.002.

Wasif, I., Josephson, P.E. and Styhre, A. (2008). Individual learning in construction projects: Professions and their approaches. The Australasian Journal of Construction Economics and Building, 8(2): 50-60. https://doi.org/10.5130/ AJCEB.v8i2.3006. 